\title{
Buyer Behaviour towards Fast Food with Special Reference to Chicking Restaurants
}

\author{
K P Najeemudeen* and N Panchanatham ${ }^{\dagger}$
}

\section{Abstract}

The Indian Fast Food Industry has witnessed high growth strides in the past years, with increasing disposable income, exposure to a number of cuisines and consumers' willingness to experiment a mix of both western and local menu. Apart from this, busy life schedule, standardized food and less time consuming processes are also fuelling the demand from domestic consumers in the industry. ChicKing is one such fast food conglomerate, specializing on fried chicken using a special recipe, spanning over a network of more than 70 outlets world over. This paper tends to analyze the buyer behaviour towards fast food restaurants based a on a questionnaire survey administered on the customers of 3 branches of Chicking Restaurant in Malappuram district of Kerala. The evaluations were done based on the responses marked in the 105 completely filled questionnaires among the total

\footnotetext{
* Assistant Professor, Nehru School of Management, Thiruvilwamala, Kerala and Research Scholar, Karpagam University, Coimbatore, Tamilnadu; India: najeemudeenkp@gmail.com

† Professor, MBA Department, Annamalai University, Tamilnadu and Research Supervisor, Karpagam University, Coimbatore, Tamilnadu; India; Panchanatham@gmail.com
} 
150 circulated. Statistical tools like Percentage Analysis and Weighted Average Score test have been used for meaningful analysis and clear presentation. This study flashes light upon some unknown factors regarding the buyer behaviour towards fast food restaurants.

Keywords: Attitude, Buyer, Consumer Behaviour, Fast Food, Fried Chicken, Perception.

\section{Introduction}

It has been a noticeable trend that food consumption pattern of urban Indian families has changed dramatically with the times owing to the growing influence of Western culture. Indians have started dining out and moved on to accept different varieties of delicious food from the world. Further, studies indicate a radical change in the consumption patterns of Indian consumers, who have traditionally been known for their price consciousness. Instant food is scoring over traditional food due to influence of Western countries and rise in income and subsequent standard of living, convenience, etc. As a result, fast food menus are gaining wider acceptance from the Indian consumers who do not want to spend much time in cooking in the middle of their hectic lifestyles.

As per a new research report titled 'Indian Fast Food Market Analysis', there has been a major shift in food habits in the metropolitan cities. About 86 per cent of households prefer to consume instant food over traditional food. Currently the Indian fast food industry stands at a massive size of $\$ 47$ billion, driven by a growing number of working professionals and increasing westernization. This industry at the moment thrives on international appeal endorsed by niche chains. The development of nutritious and healthier replacements for the traditional servings at fast food restaurants has transformed into mass promotion of portable food. It has not only provided convenience to people who shuttle between home and work for a bigger part of the day but also eliminated the requirement of conventional cutlery. As demand for all types of fast food items are consistently on the rise, pizza, burger, and French fries have become the all time favorite among young Indians, more so with some of the well-known 
burger and pizza restaurants like McDonald's, Domino's, KFC, Pizza Hut, Chicking etc, operating in India.

Various initiatives by the Government of India in the recent past have resulted in the entry of many international Fast Food Retailers in the country. With the economic liberalization in 1991, nearly all tariff and non-tariff barriers have been removed or minimized in India that has helped many retailers to enter the growing Indian fast food industry. This foray of multinational fast food retailers into India has impacted the taste buds of Indian consumers significantly. Chicking is one such brand who recently forayed into the Indian market after commencing its operations in the GCC. Owned by an Indian this company has tasted success within a short span of time with its innovative cuisine and top class customer service. This study tends to analyse the buyer behaviour towards fast food chains with special reference to Chicking Fried Chicken Restaurants.

\section{About Chicking Restaurants}

ChicKing is a rapidly growing fast-food chain in the region, specializing in serving the tastiest crumb fried chicken using a secret recipe which includes a unique blend of the choicest herbs and spices serving 'Real Recipe, Real Taste, Real Fried Chicken' since the year 2000. ChicKing has grown from a single unit outlet to a conglomerate having more than 70 outlets world over. ChicKing, established as Al Bayan Foods, is a part of the highly reputable and renowned Dubai based Al Bayan Group of Companies and\& a registered trademark of Banquet Foods International, RAK-FZE, UAE. From starting an outlet in UAE, they have spread their wings to not just the GCC, but to different countries/continents around the world including Oman, Saudi Arabia, Kuwait, Bahrain, Sudan, South Sudan, Kenya, Tanzania, Singapore, Malaysia and India under the stewardship of its Founder cum Managing Director, Mr. A K. Mansoor - Al Bayan Group of Companies.

ChicKing began its journey with a simple yet determined dream To create a brand that brings happiness, satisfaction and smiles to their customers world-over. Over the years, they have successfully realized this dream by making ChicKing a favorite destination for 
real and tasty fried chicken. ChicKing - a brand that has been built with over a decade of commitment and unmatched quality continues to make tremendous strides within its sphere of business. ChicKing offers the complete dine-in outlets experience worldwide. All restaurants have spacious sit-down dining with a carpet spread of 800-2000 sq. $\mathrm{ft}$. These restaurants are located in places with a mix of local and floating population, like shopping malls, hypermarkets and high street locations. These restaurants also have play areas for children, thus providing a complete experience full of fun, food and relaxation.

With ambitious global plans and unbeatable product range, a strong corporate backing and a robust reputation across its worldwide operations, ChicKing is expanding in Africa, Middle East, and Asian Market. With its brand potential and growth prospective, ChicKing is well on its way to achieving the status of best fast-food chain of restaurants.

\section{Review of Literature}

According to Shetty (2002), rising Americanization of eating out had tracked a culture of fast food and provide more importance to convenience and eating out behaviour due to such certain reasons, dramatic changes occurred in fast food consumption of Asian countries. Huang and Howarth (1996) have found that Structural changes in the demand for food in Asia have projected that Asian countries had been undergoing transformations in their economies supported by rapid urbanisation and this trend would continue in the years to come.

Kashyap et. al (2013), consumers in today's market are more fascinated to western culture and increase in the facilities offered by fast food services driving the growth of the industry. The frequency of visiting the fast food outlets relates with the age of the consumers as well as income that affects the spending habits of an individual. Prabhavathiet. al (2014), have observed that young, unmarried, working professionals having own lifestyle and well educated persons forms major consumer segment in fast food sector. Male and female has equal life style behaviour with regard to consumption of fast food. Taste, convenience and alternate to 
home food were found to be major reasons for consuming fast food by the young consumers.

Deivanai (2013) has concluded that convenience, family outings and celebration of special occasions are considered important in buying fast food. Customers eat out for a change from home prepared food, but they do not believe that fast food provide good nutritional value. CRISIL Research (2013) notes that, Annual spends on QSRs by middle-class households in Tier II cities are expected to surge by 150 per cent to Rs 3,750 per annum over the next three years. In comparison, annual spends in Tier I cities are expected to increase by more than 60 per cent to about Rs.6,000 by 2015-16. The quantum jump in QSR spends in urban areas will be propelled by an increase in nuclear families and working women, steady growth in incomes, changing lifestyle and eating patterns, and more importantly, greater accessibility of QSR outlets.

The report on Modern Food Processing (2013)notes that The foray of multinational fast food retailers into India has impacted the taste buds of Indian consumers significantly. Instant food is scoring over traditional food due to influence of Western countries, and rise in income \& subsequent standard of living, convenience, etc. As a result, fast food menus are gaining wider acceptance from the Indian consumers.

However, the present study differs from the above, in that the buyer behaviour in Tirur town in Malappuram district of Kerala state is sought to be analyzed here. The scope and the area of the study are unique in nature.

\section{Objectives of the Study}

The purpose of this research is to study the behaviour of consumers, perception of product attributes and level of satisfaction with respect to fast foods with special reference to ChicKing Fried Chicken Restaurants. The following are the objectives:

- To analyze the socio-economic profile of the sample respondents. 
- To identify and analyze the factors influencing the consumption of fast food.

- To understand the factors motivating the customers to dine at a fast food outlet.

- To evaluate consumers' perception and behaviour pertaining to the consumption of fast food.

\section{Scope of the Study}

The present research work is conducted within the Malappuram district of Kerala. The main reason for selecting this location for study is that this place is one of the booming markets for twowheelers in Kerala.

Malappuram, a district in the state of Kerala, India was formed on 16 June 1969 and is situated in northern Kerala very close to Kozhikode, Palakkad and Thrissur. Spanning over an area of 3550 $\mathrm{Km}^{2}$, the district consists of 2 revenue divisions, 6 taluks, 135 villages, 15 block panchayats, 7 municipalities and 100 panchayats. According to the 2011 census Malappuram district has a population of 4,110,956 and a population density of 1,158 inhabitants per square kilometer $(3,000 / \mathrm{sq} \mathrm{mi})$. Its population growth rate over the decade 2001-2011 was 13.39\%. Malappuram has a sex ratio of 1096 females for every 1000 males and a literacy rate of $93.55 \%$. Malappuram has the highest fertility rates in Kerala. Muslims $(68.53 \%)$ constitute the majority of the population, followed by the Hindu (29.17\%) and Christian (2.22\%) communities. Malappuram is one of two Muslim majority districts or Union Territories in south India.

Agriculture is the primary occupation of this district supplemented by other industries like timber industry, fishery, tourism, textile and spice trading. Wood related business is in the district is the biggest money spinner with more than hundred industries dealing with wood. The income earned abroad by the native migrants in Middle-East is a significant source of revenue to the district. 


\section{Limitations of the Study}

- The time available at the disposal of the researcher was limited for an independent study.

- The number of respondents interviewed for this study is limited to the visitors of 3 branches of a fast food brand called Chicking in Malappuram district of Kerala.

- Respondents lack of time to give information and casual attitudes.

\section{Research Methodology}

A sample of 150 consumers (50 each from 3 branches) of Chicking Restaurants in Malappuram district of Kerala was studied for this research. A structured questionnaire was designed and administered among the respondents to give a fair representation to various attributes of the consumers. A total of 150 Interview schedules were prepared and out of this, only 120 interview schedules were filled up and collected. A scrutiny of these schedules led to the rejection of 15 interview schedules on account of incomplete responses. Thus 105 completed interview schedules were used for the present study. The secondary data has been collected from various published articles, journals, magazines and also through the internet. For the purpose of evaluation, the statistical tools like Percentage Analysis and Weighted Average Score test have been used for meaningful analysis and clear presentation.

\section{Socio-Economic Characteristics of the Respondents}

A proper knowledge of the social, economic, cultural, behavioral, demographic and psychographic pattern of the respondents are very much crucial for the clear cut understanding of the findings of a research project and its further successful implementation. The socio-economic characteristics of the 105 respondents interviewed for this study are as below: 
Table 1: Socio-Economic Profile of the Respondents

\begin{tabular}{|c|c|c|c|}
\hline Features & Parameters & No. of Respondents & Percentage \\
\hline \multirow{5}{*}{ Age } & Up to 15 & 15 & 14.29 \\
\hline & $16-30$ & 38 & 36.19 \\
\hline & $31-45$ & 29 & 27.62 \\
\hline & $46-60$ & 18 & 17.14 \\
\hline & Above 60 & 5 & 4.76 \\
\hline \multirow{2}{*}{ Sex } & Male & 56 & 53.33 \\
\hline & Female & 49 & 46.67 \\
\hline \multirow{8}{*}{ Occupation } & Government Staff & 26 & 24.76 \\
\hline & Businessmen & 8 & 7.62 \\
\hline & Private Job & 27 & 25.71 \\
\hline & NRI & 12 & 11.43 \\
\hline & Student & 19 & 18.10 \\
\hline & Agriculture & 4 & 3.81 \\
\hline & Daily Wage & 6 & 5.71 \\
\hline & Retired/Unemployed & 3 & 2.86 \\
\hline \multirow{5}{*}{$\begin{array}{l}\text { Monthly } \\
\text { Income }\end{array}$} & upto 15,000 & 23 & 21.90 \\
\hline & $15001-30000$ & 19 & 18.10 \\
\hline & $30001-45000$ & 30 & 28.57 \\
\hline & Above 45000 & 16 & 15.24 \\
\hline & No Income & 17 & 16.19 \\
\hline \multirow{4}{*}{$\begin{array}{l}\text { Education } \\
\text { Qualification }\end{array}$} & Up to Matric level & 18 & 17.14 \\
\hline & Intermediate & 29 & 27.62 \\
\hline & Graduate & 44 & 41.90 \\
\hline & $\begin{array}{l}\text { Post Graduate } \\
\text { and Above }\end{array}$ & 14 & 13.33 \\
\hline \multirow{2}{*}{$\begin{array}{l}\text { Marital } \\
\text { Status }\end{array}$} & Married & 78 & 74.29 \\
\hline & Single & 27 & 25.71 \\
\hline \multirow{4}{*}{ Family Size } & 2 members & 12 & 11.43 \\
\hline & 3 members & 31 & 29.52 \\
\hline & 4 members & 26 & 24.76 \\
\hline & More than 4 members & 36 & 34.29 \\
\hline \multirow{2}{*}{$\begin{array}{l}\text { Regional } \\
\text { Background }\end{array}$} & Urban & 74 & 70.48 \\
\hline & Rural & 31 & 29.52 \\
\hline
\end{tabular}

Source: Primary Data 


\section{Data Analysis and Interpretation}

The customers' responses regarding their frequency of visit to the ChicKing restaurants, with whom they visit, when they visit, amount spent on a single visit, sources of information about the restaurant, influencers in the decision making related to the selection of restaurants etc can be well understood from the below table.

Table 2: Customers' Buying Behaviour with respect to Chicking Restaurants

\begin{tabular}{|l|c|c|}
\hline \multicolumn{1}{|c|}{ Questions \& Responses } & $\begin{array}{c}\text { No. of } \\
\text { Respondents }\end{array}$ & Percentage \\
\hline How often do you eat at Chicking Restaurant? & 1 & 1 \\
\hline Once in a Week & 22 & 21 \\
\hline Once in a Month & 5 & 5 \\
\hline Twice in a Month & 77 & 73 \\
\hline Occasionally & 31 & 30 \\
\hline How did you come to know about Chicking? & 10 & 10 \\
\hline From Friends/Colleagues & 54 & 50 \\
\hline From Family/ Relatives & 10 & 10 \\
\hline Through Advertisements & 45 & 43 \\
\hline From Fliers \& Notices & 14 & 13 \\
\hline Who influence you to go to Chicking? & 18 & 17 \\
\hline Friends & 9 & 9 \\
\hline Relatives & 19 & 18 \\
\hline Colleagues & 60 & 57 \\
\hline Spouse & 33 & 31 \\
\hline Children & 6 & 6 \\
\hline With whom do you prefer to visit Chicking? & 6 & 6 \\
\hline Family & 76 & 72 \\
\hline Friends & 19 & 18 \\
\hline Colleagues & 10 & 10 \\
\hline Alone & \multicolumn{2}{|l}{} \\
\hline How do you prefer to have food at Chicking? & \multicolumn{2}{|l|}{} \\
\hline Dine at the Restaurant & \multicolumn{1}{|l|}{} \\
\hline Take Away Parcel & \multicolumn{1}{|l|}{} \\
\hline Get Home Delivery & \multicolumn{1}{|l|}{} \\
\hline
\end{tabular}




\begin{tabular}{|l|c|c|}
\hline \multicolumn{1}{|c|}{ Questions \& Responses } & $\begin{array}{c}\text { No. of } \\
\text { Respondents }\end{array}$ & Percentage \\
\hline What time do you think is the best to dine at Chicking? \\
\hline Noon Time & 12 & 11 \\
\hline Evening & 45 & 43 \\
\hline Night & 48 & 46 \\
\hline What is your preferred occasion to dine at Chicking? \\
\hline Festivals & 17 & 16 \\
\hline Weekend/Holidays & 41 & 39 \\
\hline Special Occasions/Celebrations & 47 & 45 \\
\hline How much you will spend on average during a visit? & \\
\hline Up to Rs.500 & 18 & 17 \\
\hline Rs.501 - Rs.1000 & 42 & 40 \\
\hline Rs.1001 - Rs.1500 & 33 & 31 \\
\hline Rs.1501 - Rs.2000 & 7 & 7 \\
\hline Above Rs.2000 & 5 & 5 \\
\hline
\end{tabular}

\section{Source: Primary Data}

According to Table 1, 73\% of the respondents have responded that they use to visit ChicKing Restaurant occasionally where as $21 \%$ of the respondents visits once in a month. $5 \%$ of the respondents visit twice in a month, while only $1 \%$ of them visit this restaurant once in a week. The table also shows that $51 \%$ of respondents have stated that advertisements are their primary source of awareness about the brand, while $30 \%$ of the respondents were informed by their friends and colleagues. Ten percent of the respondents got information from the fliers and notices circulated by the restaurant, whereas $9 \%$ of them came to know about the brand from their family members and relatives. Table 1 further indicates that $43 \%$ of the respondents have stated that they are influenced by their friends to have food at Chicking Restaurants, while $18 \%$ respondents are influenced by kids. Seventeen percent respondents visit the restaurant due to the influence of their colleagues and 13\% are influenced by their relatives, whereas $9 \%$ of the respondents are motivated by their spouse. Also, $57 \%$ of the respondents have stated that they prefer to dine at Chicking Restaurant with their family, while $31 \%$ likes to visit with friends. Another $6 \%$ of the respondents like to visit with colleagues; another $6 \%$ likes to visit alone. Seventy Two (72\%) of the respondents mentioned that they prefer to consume Chicking Fried Chicken at the restaurant itself, 
while $18 \%$ liked to take away and 10 are interested in getting it home delivered. Forty six percent of the respondents have stated that they prefer night time to dine at Chicking restaurant while $43 \%$ preferred evening time and only $11 \%$ liked to dine in during the noon time. Forty five percent of the customers prefer to dine at ChicKing restaurants during special occasions and for celebrations, while $39 \%$ favour weekends/holidays, only 16\% consider festivals as the right occasion for dining at ChicKing restaurants. When it comes to the amount spent on a visit, Table 1 shows that $40 \%$ of the respondents spent somewhere between Rs.501-1000 during a visit to the ChicKing restaurant, while $31 \%$ spends an amount in the range of Rs.1001-1500, 17\% customers spent below Rs.500, 7\% and $5 \%$ of the customers spent Rs.1501-2000 and above Rs.2000 respectively on a single visit.

\section{Reasons for Visiting Chicking Restaurant}

There may be different motives for people to dine from a particular fast food outlet. In this study an inquiry was made in to the factors motivating the customers to dine at ChicKing Restaurants using six variables, namely, Convenience, Ambience, Taste of food, Pleasure of dining out, Brand Image and Sense of Pride. Table 3 shows the ranking of the responses marked by the respondents.

Table 3: Ranking of the Customers' Reasons for Visiting Chicking Restaurant

\begin{tabular}{|l|c|c|c|c|c|c|c|c|c|c|c|c|c|c|}
\hline \multicolumn{1}{|c|}{ Feature } & $\mathbf{1}$ & $\mathbf{W S}$ & $\mathbf{2}$ & $\mathbf{W S}$ & $\mathbf{3}$ & $\mathbf{W S}$ & $\mathbf{4}$ & $\mathbf{W S}$ & $\mathbf{5}$ & $\mathbf{W S}$ & $\mathbf{6}$ & $\mathbf{W S}$ & $\begin{array}{c}\text { Total } \\
\text { WS }\end{array}$ & Rank \\
\hline Convenience & 33 & 198 & 9 & 45 & 14 & 56 & 17 & 51 & 17 & 34 & 15 & 15 & 399 & $\mathbf{6}$ \\
\hline Ambience & 41 & 246 & 13 & 65 & 15 & 60 & 14 & 42 & 18 & 36 & 4 & 4 & 453 & $\mathbf{4}$ \\
\hline $\begin{array}{l}\text { Taste of } \\
\text { food }\end{array}$ & 63 & 378 & 10 & 50 & 12 & 48 & 9 & 27 & 8 & 16 & 3 & 3 & 522 & $\mathbf{1}$ \\
\hline $\begin{array}{l}\text { Pleasure of } \\
\text { dining out }\end{array}$ & 49 & 294 & 18 & 90 & 19 & 76 & 11 & 33 & 5 & 10 & 3 & 3 & 506 & $\mathbf{2}$ \\
\hline Brand Image & 45 & 270 & 16 & 80 & 17 & 68 & 12 & 36 & 8 & 16 & 7 & 7 & 477 & $\mathbf{3}$ \\
\hline $\begin{array}{l}\text { Sense of } \\
\text { Pride }\end{array}$ & 36 & 216 & 11 & 55 & 16 & 64 & 15 & 45 & 19 & 38 & 8 & 8 & 426 & $\mathbf{5}$ \\
\hline
\end{tabular}

Source: Primary Data 
We can clearly understand from the above table that Taste of the food is the main reason that motivates the customers to dine at Chicking restaurant followed by pleasure of dining out, brand image, ambience inside the restaurant, customers' sense of pride and convenience.

\section{Likeable Factors}

This study also tends to identify the factors/facilities liked by the customers the most with respect to the Chicking Restaurants upon 6 variables, namely, Kids Play Area, Parking Facility, Cleanliness, Friendly Staff, Interior Style and Promptness in Service. Table 4 shows the ranking of the responses marked by the respondents.

Table 4: Ranking of Factors liked by the Customers about the Chicking Restaurant

\begin{tabular}{|l|c|c|c|c|c|c|c|c|c|c|c|c|c|c|}
\hline \multicolumn{1}{|c|}{ Feature } & $\mathbf{1}$ & WS & $\mathbf{2}$ & WS & $\mathbf{3}$ & WS & $\mathbf{4}$ & $\mathbf{W S}$ & $\mathbf{5}$ & $\mathbf{W S}$ & $\mathbf{6}$ & $\mathbf{W S}$ & $\begin{array}{c}\text { Total } \\
\text { WS }\end{array}$ & Rank \\
\hline $\begin{array}{l}\text { Kids Play } \\
\text { Area }\end{array}$ & 45 & 270 & 16 & 80 & 17 & 68 & 12 & 36 & 8 & 16 & 7 & 7 & 477 & 3 \\
\hline $\begin{array}{l}\text { Parking } \\
\text { Facility }\end{array}$ & 33 & 198 & 9 & 45 & 14 & 56 & 17 & 51 & 17 & 34 & 15 & 15 & 399 & 6 \\
\hline Cleanliness & 63 & 378 & 10 & 50 & 12 & 48 & 9 & 27 & 8 & 16 & 3 & 3 & 522 & 1 \\
\hline $\begin{array}{l}\text { Friendly } \\
\text { staff }\end{array}$ & 41 & 246 & 13 & 65 & 15 & 60 & 14 & 42 & 18 & 36 & 4 & 4 & 453 & 4 \\
\hline Interior Style & 36 & 216 & 11 & 55 & 16 & 64 & 15 & 45 & 19 & 38 & 8 & 8 & 426 & 5 \\
\hline $\begin{array}{l}\text { Promptness } \\
\text { in Service }\end{array}$ & 49 & 294 & 18 & 90 & 19 & 76 & 11 & 33 & 5 & 10 & 3 & 3 & 506 & 2 \\
\hline
\end{tabular}

\section{Source: Primary Data}

Table 4 indicates the ranking of the responses marked by the respondents on the factors/features they liked the most about Chicking restaurant. The ranking shows that Cleanliness is the major factor liked by most of the customers followed by promptness in service, play area for kids, friendly behaviour of the staff, interior style and parking facility. 


\section{Findings}

The major findings from this study are:

1. Seventy three percentage of the respondents have responded that they use to visit ChicKing Restaurant occasionally where as $21 \%$ of the respondents visit once in a month. $5 \%$ of the respondents use to visit twice in a month, while only $1 \%$ of them visit this restaurant once in a week. This implies that most of the people are not regular visitors to this restaurant, but are used to having food here only once in a while for a change.

2. Fifty one percentage of the respondents stated that advertisements are their primary source of awareness about the brand, while $30 \%$ of the respondents were informed by their friends and colleagues. $10 \%$ of the respondents got information from the fliers and notices circulated by the restaurant, whereas $9 \%$ of them came to know about the brand from their family members and relatives. From this we can understand that advertisements are the biggest source of information about ChicKing Restaurants.

3. Forty three percentage of the respondents have stated that they are influenced by their friends to have food at ChicKing Restaurants, while $18 \%$ respondents are influenced by kids. Seventeen percentage of the respondents visit the restaurant due to the influence of their colleagues and $13 \%$ by relatives, whereas $9 \%$ of the respondents are motivated by their spouse. This states that friends, kids and colleagues are the most influencing persons in the selection of a fast food restaurant.

4. Fifty seven percentage of the respondents have stated that they prefer to dine at ChicKing Restaurant with their family, while $31 \%$ likes to visit with friends. Six percentage of the respondents like to visit with colleagues, another $6 \%$ likes to visit alone. This clearly indicates that most people prefer to have food at ChicKing Restaurant with family. 
5. Seventy two percentage of the respondents mentioned that they prefer to consume ChicKing Fried Chicken at the restaurant itself, while $18 \%$ liked to take parcel and $10 \%$ are interested in getting home delivered. This shows that majority of the customers prefer to dine at the restaurant than take away or home delivery.

6. Forty six percentage of the respondents have stated that they prefer night time to dine at ChicKing restaurant while $43 \%$ preferred evening time and only $11 \%$ liked to have it during noon time. This shows that the time between 4 PM$11 \mathrm{PM}$ is the best time for dining at ChicKing restaurant and no one is interested to eat during the early hours of a day.

7. Forty five percentage of the customers prefer to dine at ChicKing restaurants during special occasions and for celebrations. Thirty nine percentage favours weekends/ holidays, only $16 \%$ considers festivals as the right occasion for dining at Chicking restaurants.

8. Forty percentage of the respondents spend an amount between Rs.501-1000 during a visit to the ChicKing restaurant, while $31 \%$ spends an amount in the range of Rs.1001-1500. While 17\% customers spend below Rs.500, 7\% and 5\% of the customers spend Rs.1501-2000 and above Rs.2000 respectively on a single visit.

\section{Recommendations}

1. Though the customers like the taste and flavor of the food at the ChicKing restaurants, they are not frequent visitors. Most of the customers prefer to visit only during special occasions like birthdays, anniversary etc. Hence the management should take adequate measures to increase their frequency of visit and also to attract more new customers in order to achieve better sales and profit.

2. The results indicate that advertisement is the biggest source of product information to the public. So the management should focus on extensive advertising of the product to attract more customers and boost up the sales. 
3. Friends and children are the main influence for visiting ChicKing restaurant. Hence the promotional strategies and customer service should be streamlined in such a way that it derives more word-of-mouth publicity.

4. Most of the customers prefer to visit fast food restaurants in groups rather than alone. Hence more special schemes and offers should be planned and implemented for group customers.

\section{Conclusions}

Consumer Behaviour consists of all human behaviour that goes in making purchase decisions. An understanding of the consumer behaviour enables a marketer to take marketing decisions which are compatible with its consumer needs. There are four major classes of consumer behaviour determinants and expectations, namely, cultural, socio-economic, personal and psychological. If the challenges are met with serious considerations, the Indian fast food industry is anticipated to achieve glorious milestones in the coming years. Increasing inclination of people to eat outside (restaurants) will be the major driving force behind the projected growth. Besides, healthy food options and low-price menu has also contributed to its growth, to attain a CAGR of around 33 per cent during 2010-2015. Moreover, continuous economic growth and improving employment situation will lead to higher personal expenditures on outside food by 2015. Also certain product attributes are identified as having a greater influence over the purchase decision of the customers and satisfying them. The manufacturers and marketers who study the behaviour of consumers and cater to their needs will be successful. It may be concluded that consumer behaviour has a greater role to play in the LPG era of economic activities for which a necessary survey and research should be conducted in an efficient manner.

\section{References}

CRISIL Research. (2013). Organised fast food in the fast lane.

Deivanai P. (2013). A study on consumer behaviour towards fast food products with special reference to Domino's Pizza. 
International Research Journal of Business and Management, 11(5), p.13-18.

Huang, Jikun \& Bouis, Howarth. (1996).Structural changes in the demand for food in Asia. Vision Brief, 4(1), p. 41-48.

Modern Food Processing (Infomedia18). (2014).Indian fast food industry on a quick and smart growth drive.

Minal Kashyap, Komal Kashyap \& Anil Sarda. (2013). A study of growth of fast food industry with reference to shift in consumer's buying habits in Nagpur city. International Journal of Application or Innovation in Engineering \& Management, 2(3), p.12-18.

Prabhavathi Y., Krishna Kishore N.T \& Ramesh Kumar M.(2014). Consumer preference and spending pattern in Indian fast food industry. International Journal of Scientific and Research Publications, 4(2), p.16-22.

Prakash Shetty\& Josef Schmidhuber. (2011). Nutrition, lifestyle, obesity and chronic disease. Population Division Expert Paper No. 2011/3, United Nations, New York. 